\title{
Researcher battles CNRS reforms
}

The French are not unaccustomed to antiestablishment protest, but the latest revolt against government reform is headed by a heroine as unlikely as Joan of Arc.

Claire Lemercier, a 31-yearold researcher at the École Normale Supérieure in Paris, seemingly appeared from nowhere to help spearhead a movement that last week forced key concessions to a major government reform of the CNRS, Europe's largest basicresearch agency.

It all began in early June, when Lemercier heard that she was to receive the top medal for promising young researchers, an annual CNRS award. The government had just announced that the CNRS was to be broken up into six quasiautonomous national institutes, a move widely interpreted as a dismantling of the agency.

The medal "immediately made me think of the orchestra playing on as the ship sinks", says Lemercier. She decided to rally other medallists to protest against the CNRS reforms and to show that the protest was not limited to left-wing trade unions and researchers scared of greater competition, but also included award-winning scientists.

Success was immediate. More than 450 medallists, including the cream of French science, have endorsed her text (http://medailles.rechercheenseignement-superieur.fr), which protests at aspects of the CNRS reforms, and a lack of staff and budgetary resources to implement them.

"I was pleasantly surprised at how many renowned medallists signed up - people far better known than me. I'm just the last in of the medallists," Lemercier says.

Lemercier's initiative gave fresh and timely momentum to researchers who were already resisting the reforms and generated broad media attention. Libération newspaper ran a full-page profile on Lemercier, describing her as a thorn in the ministry's side under the headline "Gunslinging chick".

The protest movement culminated in more than 1,000 researchers invading the CNRS's Paris headquarters on 19 June and preventing the agency's board from adopting the reform. Science minister Valérie Pécresse has since made concessions that trade unions say saves the CNRS from being immediately dismantled, although they remain vigilant.

Whereas the principle of hiving off the CNRS into national institutes is retained, the revised reform would guarantee that all CNRS disciplines are represented - life sciences, the CNRS's largest discipline, as well as computing, had been relegated in the initial reform to departments. "This concession is really important, although we are still worried about how it will pan out concretely in practice," says Lemercier.

Moreover, the CNRS, and not the government as was planned, will now appoint the heads of the institutes. This latter move had been widely perceived as an attempt by the government to take control of the CNRS. The agency will now be fully

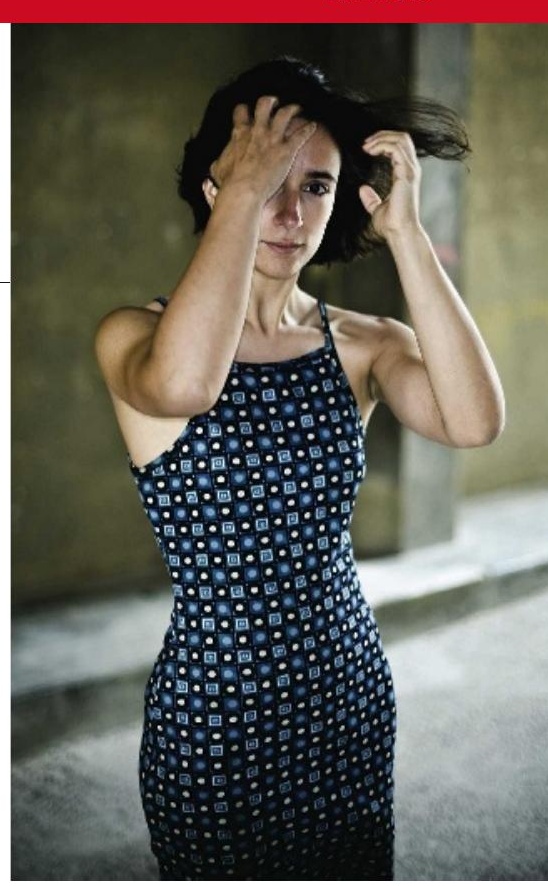

Claire Lemercier, 'gunslinging chick'?

responsible for planning and managing the institutes, which will run their own laboratories. And for the first time, they will also act as research councils, giving grants to outside labs. That is something many researchers welcome, says Lemercier.

The new reforms were adopted by the CNRS board last week, but the details will not be thrashed out until the autumn. For her part, Lemercier says she has no ambitions to pursue her activist career further, and is keen to get back to her research.

Declan Butler

\section{Scientists rally to Mexican researchers' plea}

Scientists from around the world are calling on Mexican leaders to resolve a dispute that is tearing apart a leading South American research institute.

Two nanotechnology researchers at the Institute for Scientific and Technological Research of San Luis Potosí (IPICYT) claim they are being persecuted by the organization's administrators, after they testified in a longrunning probe into the former director, José Luis Morán-López, who was ousted for nepotism in April. Morán-López denies impropriety and is appealing.

Both researchers, brothers Humberto and Mauricio Terrones Maldonado, have since lost their administrative posts. Humberto was head of the advanced-materials department, and Mauricio headed the graduate research programme. Their students claim that the current administrators are now transferring lab facilities funded by the Terrones' grants to others.

The Terrones appealed to prominent scientists, including Nobel-prizewinning chemist Harold Kroto, one of the discoverers of 'buckyball' molecules. Last week, Kroto and 30 other scientists signed a letter in support of the pair, addressed to Mexican President Felipe Calderón Hinojosa and Mexico's national council of science and technology funding (CONACYT).

Kroto says that he fears the attacks on the Terrones will destroy one of Latin America's most promising physical-science centres and drive the two researchers abroad. "The Terrones could easily have won research positions anywhere, but they chose to go back to Mexico to help young scientists," says Kroto, who is based at Florida State University in
Tallahassee. "They have made a massive contribution to science. They now have had a kick in the teeth."

"The solidarity of the international community has been overwhelming," says Humberto. "What we want is Mexican leaders to solve the problem. Our system doesn't seem to allow for success of young scientists."

The institute's current department heads responded to the scientists' letter on 28 June. In a letter to Kroto, they decry his involvement in the affair, writing that his actions are "unbalanced, based on false premises and damage the prestige of our institute". Current IPICYT director David Rios Jara told Nature that the Terrones are very ambitious and "the only way they will be quiet is when they have their own centre. They don't like authority."

Rex Dalton 